\title{
Customer Loyalty and Powerful Brand in Heavy Machinery Industry
}

\author{
Omidreza Ghanadiof
}

\section{ABSTRACT}

\begin{abstract}
Market of the heavy machinery industry is growing fast. Customers have choices in purchasing new or used equipment or they can decide to rent or leas. Today's brand concept embraces all the things that a product or service offers, including how a product shapes consumers' behavior. The brand's special value is the perception that consumers have to a brand, which is perceived by many factors. This research is based on the Keller model, which includes the main four criteria's: brand awareness, brand association, perceived quality, and brand loyalty.
\end{abstract}

The most important reason that customers would changes suppliers is the lack of providing services and products based on customer needs. Through this case study the company, TECHNOCAT, seeks to understand the correlation of the brand and customer repurchases, whether the value of the brand affects customer decisions in future purchases. The researcher conducted a survey study. The expert panels in the field validated a questionnaire; Cronbach's alpha coefficient is 0.82 for reliability testing. Managers of the mining businesses and owners of machines are the target population. Statistical Package for Social Science (SPSS) version 23.0 with descriptive statistics and multiple regression were utilized for data analysis, and AMOS was used for the structural equations. The finding presented results from 132 respondents. The study showed that there is a significant relationship between brand equity with an intention to buy again. Furthermore, certain factors; awareness, quality, loyalty, and association with the intention of re-buying, have significantly influence on repurchasing.

Keywords: Branding, B2B, Brand awareness, Consumer Behavior.

\author{
Submitted : June 01, 2021 \\ Published : June 23, 2021 \\ ISSN: $2507-1076$ \\ DOI: $10.24018 / \mathrm{ejbmr} .2021 .6 .3 .903$ \\ Omidreza Ghanadiof \\ Graduated of Industrial Management, \\ School of Technology, University of \\ Central Missouri, USA. \\ (e-mail: omidof90@gmail.com)
}

\section{INTRODUCTION}

There have been few studies on customer loyalty and powerful brand in the heavy machinery industry. The purpose of this study is to investigate the relationship between the brand and customer repurchase intention, whether the value of product brand may affect customer decisions in future buying. Promoting a brand name in many cases becomes an organization's strategy [11]. People who are branded are looking for quality or specific features that make it special or unique [19]. Customer loyalty is one of a particular product or trademarks is very important because it would be most property of a company. Empirical research shows that the cost of attracting a new customer is 25 to 411 percent more than the cost of maintaining current customers. Thus, adding up to $5 \%$ to the cost of maintaining its current customers can add up to $75 \%$ to the company's profitability. Of course, the analysis is based on the assumption that current customers are profitable. In other words, the value of their life cycle (realized revenue from the place they buy during the time they buy from the firm, minus the costs necessary to maintain them) is positive. Today, the brand concept is all that the product or service delivers Including how a product is shaping consumers' feelings and thoughts is a brand-name commitment to deliver value to consumers. There have been few studies on customer loyalty and powerful brand in the heavy machinery industry. The purpose of this study is to investigate the relationship between the brand concept and intention to repurchase. The heavy machinery industry has grown in the past years [19]. To increase sales, it is important to learn about customer behavior and product's brand. 


\section{LITERATURE REVIEW}

Major Points:

- Literature reviews on role of powerful brand and customer repurchase intention in heavy machinery industry.

- Research hypothesis testing relationship between certain factors (brand awareness, brand association, perceived quality, and brand loyalty) and influence on buying.

- A discussion on brand equity and customer loyalty.

- Interview data from expert panels regard to utility criteria of business owners.

[27] believed to measure the brand power concept, one of this method can always be brand equity or the nominal value of each share in the stock of that market and its intention in this. This researcher uses the brand equity to understand the relationship.

\section{HYPOTHESIS}

1. Brand equity has a significant effect on the re-purchase of machinery parts.

2. Brand loyalty has a significant effect on re-purchasing in heavy machinery market

The customer is like a blood vessel in the organization and having the information about the customer, the organization is capable makes it possible to produce goods and services tailored to the needs of the customers of the company.

The survey findings show positive relationship between brand equity with intention to buy again. This research can assist the heavy equipment business to improve their strategic plans, product quality, and sales. The brand's Equity is the perception that consumers have of the brand, which is perceived by many of the factors undergoing change. Brand equity cannot be understood without taking into account and its resources. The factors that contribute to the creation and formation of brand equity in the minds of consumers. [3] for the first time introduced the brand equity dimension and, in later supplementary research, this research became finally to these dimensions (brand awareness, brand loyalty, and perceived quality as brand equity dimensions). Positive brand equity, in turn, can leads to higher earnings, lower costs and higher profits, and has direct effects on the organization's ability to make appropriate decisions about product price increases [15], the effectiveness of marketing communications, and the success of business develop.

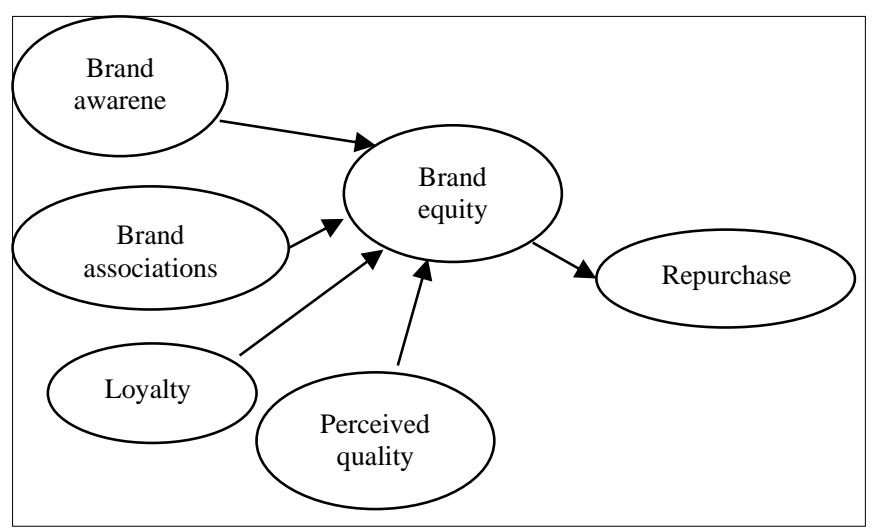

Fig. 1. Concept Model.

\section{DEFINITION}

The definition of the customer depends on the market in which the transaction occurs. If the transaction is in a consumer market happens, the customer can be a consumer or a user or employee; but if it is in the industrial market, customer is a supplier. B2B markets include the complex relationships of market participants on both sides of the deal. Therefore, we can say that product markets in B2B environments are at least as efficient as consumer markets most likely more efficient. In addition, the positive range of customer satisfaction in B2B markets is at least as large as consumer markets [31] There are significant differences between the customer in the industrial or B2B markets and B2C markets. The most important difference is that the purchasing behavior different from the final consumer of goods and services.

\section{A. Quality}

Each product or service has different aspects that create expectations for the customer. They would expect after buying products to feeling happy.

Major differences include:

1 The consumer population in the consumer markets is larger than the industrial market.

2. The volume of industrial purchases is usually higher than the volume of sales in consumer markets.

3 . The nature of relationship between the customer and seller in institutional markets is completely different [25].

4. Consumers generally have less knowledge in comparison of B2C's customers for goods and services in B2B market.

\section{B. Repurchase}

The word re-purchase is described as a behavioral concept that tends to repeat a transaction to buy a product or service because of different internal causes [21]. Experts say that the intention to repeat consumer purchases is linked to their beliefs. Understand the consumer's quality of service is a one of main factor affecting the formation of a behavioral intention. Today, organizations believe that only by loyal customers they would be able to achieve long-term profits. Therefore, they are always striving to facilitate the customer re-purchase process. As most researchers have said, it is the intention to re-purchase the customer loyalty behavioral indicator. The brand should be able to capture the hearts and minds of its audience. In today's world where its markets are packed with products that are not physically different, creating a personality suitable for a brand can create a significant difference.

\section{Brand Equity}

According to the opinion of marketing researchers, the concept of brand strength can be considered as one brand equity [29] By considering this important point in this paper, the concept of brand is brand equity. Additionally, it is important to know tangible effects of raising customer with buying and profitability of companies.

The brand value a value added for the company, trade and consumer brand that is granted to the product [3] recognizes brand equity as a set of assets and capabilities related to a brand that adds or deducts value for the product and service for the company, customers, or both. 


\section{Loyalty}

Brand loyalty has been defined in terms of behavioral, attitudinal and selective approaches [13]. In another, brand loyalty is under the so-called brand resonance that addresses the nature of customer-based relationships and the extent to which customers feel aligned with and fit with Come back [3].

\section{Brand associations}

A brand association recognizes everything that is reflected by the brand's attributes in memory. Brand consistency and association can be seen in all forms and attributes associated with a commodity or aspects that are independent of the goods themselves.

\section{Brand awareness}

The buyer's ability is to identify and remind brand, specification, or logo brand that are in the particular category of products or services. Brand awareness refers to the power of intelligence groups about a brand in one's memory [2].

\section{Perceived quality}

Customer perception of the quality or superiority of a product or service with the perception of "perceived quality as a definition" to the purpose of that product or service to the other products services available on the market. Usually when perceived value is at a high level, customers experience become positive about this brand and their satisfaction with the product or service increases, which plays an important role in creating customer loyalty to the brand [34].

\section{MethodOLOGY}

Considering that the purpose of this research is to analyze the brand equity and its effect on repurchase intention, so data collected from owners of machinery. The statistical population of this study is consisting of 211 owners in this city. The method used in this research is stratified random sampling. Considering the fact that the number of studied populations is 211 of the miners in Isfahan city. For this reason, we used the formula "Krejcie Morgan" to determine the sample size. There were 141 distribution questionnaires, out of which 132 questionnaires were returned. Among the various types of questionnaires available in this study, the five-level spectrum Likert scale (1 to 5) (which is the lowest score and the fifth is the highest score). The designed questionnaire is a combination of standard questions and elite approvals for this strategy.

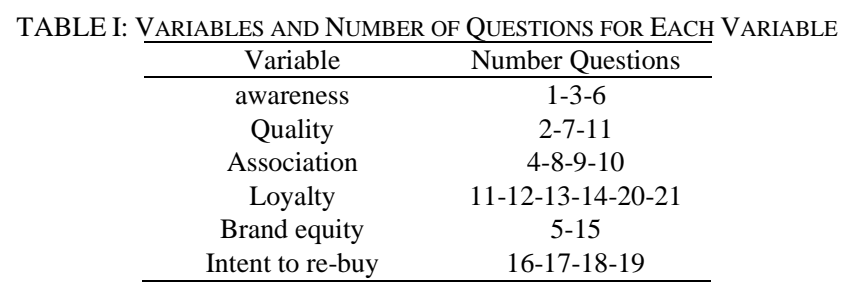

\section{A. Validity}

The concept of validity addresses the question of how much the instrument measures to what extent. It can be assured that the accuracy of the data obtained cannot be guaranteed without the knowledge of the validity of the measuring instrument [16]. In this research, to investigate the validity of the collective questionnaire of the past and present marketing experts have been used.

\section{B. Reliability of the Questionnaire}

Reliability is one of the technical features of measuring instruments [14]. Reliability determines that the measuring tool is in the same conditions give the same results. In this research, Cronbach's alpha method was used to determine the reliability of the test. Due to the variance of each of the questions as well as the variance of the whole test was obtained. Cronbach's alpha coefficient [32]. By utilizing SPSS we understand that our Cronbach's .82. Therefore, considering in the humanities research, alpha coefficient is higher than .75 , so the reliability of the questionnaire can be evaluated well.

\section{RESULTS}

\section{A. Pearson Correlation Test}

The Pearson correlation coefficient, $r$, can take a range of values from +1 to -1 . a value of 0 indicates that there is no association between the two variables. A value greater than 0 indicates a positive association; that is, as the value of one variable increases, so does the value of the other variable. A value less than 0 indicates a negative association; that is, as the value of one variable increases, the value of the other variable decreases.

\section{B. Relationship between Brand Equity with the Intention of Re-buying}

This test show that the correlation coefficient of brand equity and intent- Re-purchasing, with $95 \%$ confidence, is statistically significant, so this correlation coefficient meaningful [12]. As a result, the zero assumption on the absence of the corresponding coefficient is rejected. The statistical results of the hypothesis 1 , which is somewhat positive and therefore the main one is that the correlation coefficient is \%846. It indicates a positive relationship between these two variables. In other words, it can be said with increasing levels Brand equity, rebate level also increases. Therefore, the main result can be in the form the following is stated:

"There is a significant relationship between brand equity with the intention of re-buying".

\section{Sub-hypothesis One}

The findings of the report indicate that the correlation coefficient of awareness and the intention of re-purchasing, with $95 \%$ confidence, are statistically significant, so this correlation coefficient is significant. As a result, the zero assumption on the absence of a corresponding coefficient is rejected. The results of the statistical analysis are the main hypothesis, which is a positive and therefore indicative of the relationship / expression, the correlation coefficient is $432 \%$ positive between these two variables.

\section{Second Sub-hypothesis}

The findings of the report indicate that for correlation coefficient of quality and repurchase, with $95 \%$ confidence, is meaningful significant. Therefore, as a result, the zero assumption is based on the absence of a corresponding coefficient. The results of the statistical analysis are the main 
hypothesis, which is a positive and therefore indicates a correlation between the positive correlation coefficient of $753 \%$ between the two variables.

\section{E. Third Sub-hypothesis}

The findings of the report indicate that correlation coefficient of association and purchase-reloading with $95 \%$ confidence are statistically significant, so this correlation coefficient is significant. As a result, the zero assumption on the absence of a corresponding coefficient is rejected. The results of the statistical hypothesis of the main hypothesis indicate that a positive amount and thus the relationship between the two is that the correlation coefficient of \%661 is positive between these two variables.

\section{F. Fourth Sub-hypothesis}

Findings indicate that for correlation coefficient of loyalty and re-purchasing with $95 \%$ confidence, this correlation is significant. As a result, the zero assumption on the absence of a corresponding coefficient is rejected. The statistical results of the main hypothesis of the expression is that it is a positive and therefore indicative of a positive relationship/is the correlation coefficient of $782 \%$ between the two variables. The research model, which is based on research hypotheses, is shown in Table II. The coefficients are calculated after fitting the model to the collected data.

\begin{tabular}{|c|c|c|c|c|}
\hline $\mathrm{t}$ & Leverage & & Path & \multirow{4}{*}{ Brand awareness } \\
\hline- & $0 / 80$ & $\begin{array}{c}\text { Brand } \\
\text { Awareness 1 }\end{array}$ & $\leftarrow$ & \\
\hline $6 / 68$ & $0 / 82$ & $\begin{array}{c}\text { Brand } \\
\text { Awareness } 2\end{array}$ & $\leftarrow$ & \\
\hline $5 / 26$ & $0 / 51$ & $\begin{array}{c}\text { Brand awareness } \\
3\end{array}$ & $\leftarrow$ & \\
\hline- & $0 / 74$ & Brand Loyalty 1 & $\leftarrow$ & \multirow{5}{*}{ Brand loyalty } \\
\hline $9 / 36$ & $0 / 82$ & Brand Loyalty 2 & $\leftarrow$ & \\
\hline $9 / 43$ & $0 / 83$ & Brand loyalty 3 & $\leftarrow$ & \\
\hline $9 / 92$ & $0 / 87$ & Brand loyalty 4 & $\leftarrow$ & \\
\hline $8 / 72$ & $0 / 77$ & Brand loyalty 5 & $\leftarrow$ & \\
\hline- & $0 / 61$ & $\begin{array}{l}\text { Intention to } \\
\text { repurchase } 1\end{array}$ & $\leftarrow$ & \multirow{4}{*}{$\begin{array}{l}\text { Intention to } \\
\text { repurchase }\end{array}$} \\
\hline $7 / 44$ & $0 / 90$ & $\begin{array}{l}\text { Intention to } \\
\text { repurchase } 2\end{array}$ & $\leftarrow$ & \\
\hline $6 / 39$ & $0 / 69$ & $\begin{array}{l}\text { Intention to } \\
\text { repurchase } 3\end{array}$ & $\leftarrow$ & \\
\hline $7 / 02$ & $0 / 80$ & $\begin{array}{l}\text { Intention to } \\
\text { repurchase } 4\end{array}$ & $\leftarrow$ & \\
\hline- & $0 / 82$ & $\begin{array}{c}\text { Perceived quality } \\
1\end{array}$ & $\leftarrow$ & \multirow{3}{*}{ Perceived quality } \\
\hline $9 / 44$ & $0 / 89$ & $\begin{array}{l}\text { Perceived quality } \\
2\end{array}$ & $\leftarrow$ & \\
\hline $8 / 30$ & $0 / 70$ & $\begin{array}{c}\text { Perceived quality } \\
3\end{array}$ & $\leftarrow$ & \\
\hline- & $0 / 77$ & $\begin{array}{c}\text { Brand } \\
\text { Association } 1\end{array}$ & $\leftarrow$ & \multirow{4}{*}{ Brand association } \\
\hline $9 / 70$ & $0 / 85$ & $\begin{array}{c}\text { Brand } \\
\text { Association } 2\end{array}$ & $\leftarrow$ & \\
\hline $8 / 80$ & $0 / 77$ & $\begin{array}{c}\text { Brand } \\
\text { Association } 3\end{array}$ & $\leftarrow$ & \\
\hline $8 / 67$ & $0 / 76$ & $\begin{array}{c}\text { Brand } \\
\text { Association } 4\end{array}$ & $\leftarrow$ & \\
\hline- & $0 / 50$ & Brand equity 1 & $\leftarrow$ & \multirow{2}{*}{ Brand equity } \\
\hline $4 / 49$ & $0 / 54$ & Brand equity 2 & $\leftarrow$ & \\
\hline $3 / 55$ & $0 / 37$ & Brand equity & $\leftarrow$ & Brand awareness \\
\hline $2 / 09$ & $0 / 18$ & Brand equity & $\leftarrow$ & Perceived quality \\
\hline $4 / 99$ & $0 / 75$ & Brand equity & $\leftarrow$ & Brand association \\
\hline $3 / 88$ & $0 / 41$ & Brand equity & $\leftarrow$ & Brand loyalty \\
\hline $4 / 49$ & $0 / 80$ & $\begin{array}{l}\text { Intention to } \\
\text { repurchase }\end{array}$ & $\leftarrow$ & Brand equity \\
\hline
\end{tabular}

As can be seen in Table II, for all the coefficients of values $t$ are greater than 1.96 and therefore all of them are significant at the $95 \%$ level.

Therefore, all the questions considered in the questionnaire have a significant role in explaining the research variables (brand awareness, perceived quality, brand association, brand loyalty, brand equity and repurchase intention).

On the other hand, considering that the paths of brand awareness, perceived quality, brand association and brand loyalty to brand equity are significant and the path of brand equity to repurchase is also significant, the results are reaffirmed for research hypotheses.

The Table III shows the good range indicators of the measurement model. If the values would be in this range, they indicate the suitability of the model for the collected data.

\begin{tabular}{ccccc}
\multicolumn{5}{c}{ TABLE III: MODEL FITTING MODELS } \\
\hline$\chi^{2} / d f$ & $(S R M S R)$ & $($ RMSEA $)$ & $(T L I)$ & $(C F I)$ \\
\hline $2 / 75$ & $0 / 069$ & $0 / 064$ & $0 / 91$ & $0 / 93$ \\
$\chi^{2} / d f \leq 3 ;$ & $T L I, C F I \geq 0 / 90, R M S E A \leq 0 / 09 ;$ & SRMSR $\leq 0 / 10$ \\
\hline
\end{tabular}

TABLE IV: CORRELATION OF BRAND EQUITY ITEMS WITH EACH OTHER

\begin{tabular}{|c|c|c|c|c|c|}
\hline & & Awareness & Quality & Association & Loyalty \\
\hline \multirow{3}{*}{ Awareness } & $\begin{array}{l}\text { correlation } \\
\text { coefficient }\end{array}$ & 1 & $0 / 394^{* * *}$ & $0 / 483^{* *}$ & $0 / 367^{* *}$ \\
\hline & Sig. Value & & $0 / 000$ & $0 / 000$ & $0 / 000$ \\
\hline & Qty & 132 & 132 & 132 & 132 \\
\hline \multirow{3}{*}{ Quality } & $\begin{array}{l}\text { correlation } \\
\text { coefficient }\end{array}$ & $0 / 394^{* *}$ & 1 & $0 / 691^{* *}$ & $0 / 616^{* *}$ \\
\hline & Sig. Value & $0 / 000$ & & $0 / 000$ & $0 / 000$ \\
\hline & Qty & 132 & 132 & 132 & 132 \\
\hline \multirow{3}{*}{ Association } & $\begin{array}{l}\text { correlation } \\
\text { coefficient }\end{array}$ & $0 / 483^{* *}$ & $0 / 691^{* *}$ & 1 & $0 / 527^{* *}$ \\
\hline & Sig. Value & $0 / 000$ & $0 / 000$ & & $0 / 000$ \\
\hline & Qty & 132 & 132 & 132 & 132 \\
\hline \multirow{3}{*}{ Loyalty } & $\begin{array}{l}\text { correlation } \\
\text { coefficient }\end{array}$ & $0 / 367^{* *}$ & $0 / 616^{* *}$ & $0 / 527^{* *}$ & 1 \\
\hline & Sig. Value & $0 / 000$ & $0 / 000$ & $0 / 000$ & \\
\hline & Qty & 132 & 132 & 132 & 132 \\
\hline
\end{tabular}

\section{CONCLUSION}

As the above research shows, brand equity has a significant impact on the intention to repurchase customers in organizations and companies. In this study, using the role of four variables of brand equity in increasing the intention to repurchase customers in customers in Technoct was examined. The present study was conducted by using randomized data collection method gathered by designed survey and analyzed with SPSS software to examine hypotheses.

The proposed model is a proven model for predicting the results of data analysis and suggests that brand equity has a significant impact on repurchase intention. It can be concluded that if the brand equity that we used in this study as a concept of brand strength would increases, the intention to repurchase will also increase.

In summary, with increasing brand power level, the intention to buy has also increased Also, the variables of quality, association, awareness, and loyalty have a significant relationship with brand power.

The main hypothesis and brand equity have a significant effect on the repurchase intention of customers among the factors that make up brand equity. The greatest impact on repurchase is loyalty-quality-association and awareness, respectively. Also, there is a strong correlation $84 \%$ between 
these two variables of repurchase intention as dependent and brand value as independent, that can reveal $71 \%$ of the changes, can be dependent on this level.

\section{REFERENCES}

[1] Celik, E., Bilisik, O. N., Erdogan, M., Gumus, A. T., \& Baracli, H. (2013). An integrated novel interval type-2 fuzzy MCDM method to improve customer satisfaction in public transportation for Istanbul. Transportation Research Part E: Logistics and Transportation Review, 58, 28-51.

[2] 10-Keller, K.L. (2001). Building customer-based brand equity: a blueprint for creating strong brands. Marketing science Institute Working.

[3] Aaker, D.A. (1991), "Managing Brand Equity", The Free Press, New York, Aaker, D.A, Kdvin Lane Keller, "Concumer evaluation of brand extension", journal of marketing janury, 1990, pp. 27-40.

[4] Arıkan, E., \& Güner, S. (2013). The impact of corporate social responsibility, service quality and customer-company identification on customers. Procedia-Social and Behavioral Sciences, 99, 304-313.

[5] Atilgan, E., Aksoy, S., and Akinci, S. (2007). "Determinants of the brand equity", Marketing Intelligence and Planning, vol. 23, No. 3, pp. 237-248.

[6] Brooks, G. (February 2018) Industry outlook: heavy equipment manufacturing in 2018.

[7] Celik, Erkan. Nalan Bilisik, Ozge. Melike Erdogan, Alev Taskin Gumus, Hayri Colin Adamson (1994) How to Waste Money Measuring Customer Satisfaction" Managing Service Quality.

[8] Cooper, D. R., Schindler, P. S., \& Sun, J. (2006). Business research methods (Vol. 9, pp. 1-744). New York: Mcgraw-hill

[9] Arıkan, E., \& Güner, S. (2013). The impact of corporate social responsibility, service quality and customer-company identification on customers. Procedia-Social and Behavioral Sciences, 99, 304-313.

[10] Davis (2010) "Measurement and analysis of customer satisfaction company practices in Spain and Portugal Prado" International Journal of Productivity and Performance Management.

[11] Fardhosseini, M. S., Soltaninejad, M., Karji, A., Ghorbani, Z., \& Ghanadiof, O. (2021). Qualitative Evaluation of 5S Application Considering the Experience of Electrical Construction Experts.

[12] Miremadi, A., Kenar Roudi, J., \& Ghanadiof, O. (2021). Evaluation on Role of Electronic Word of Mouth (EWOM) Ads in Customers' Emotions and Choices in E-Shops. International Journal of Industrial Marketing, 6(1). https://doi.org/10.5296/ijim.v6i1

[13] Ghanadiof, omidreza, \& Miremadi, A. (2018). Build your brand in one week.

[14] Ghanadiof, omidreza, Miremadi, A., \& Mohammadian, M. (2021). Strategic Planning and Strategic Analysis of Food Industry Using SWOT. Scientific Research Journals in Management and Social Studies, 2(23), 14-33.

[15] Gil, R. B., Andres, E. F., \& Salinas, E. M. (2007). Family as a source of consumer-based brand equity. Journal of product \& brand management.

[16] Ha, S. H. (2007). Applying knowledge engineering techniques to customer analysis in the service industry. Advanced Engineering Informatics, 21(3), 293-301.

[17] Kapferer, J. N. (2008). The new strategic brand management: Creating and sustaining brand equity long term. Kogan Page Publishers.

[18] Davis, M. M., \& Heineke, J. (1998). How disconfirmation, perception and actual waiting times impact customer satisfaction. international Journal of Service industry Management. Management, Vol. 16, No. 3, pp. 188-199.

[19] Miremadi, A., \& Ghanadiof, O. (2021). CRM Competitive Strategy in Financial Institutions. European Journal of Business and Management Research, 6(3), 111-117.

[20] Moderating Effect of Customer Characteristics. Journal of Marketing Research, Vol. 38, N. 1(Feb.,2001), pp.131-142.Retrieved.

[21] Anderson, J. C., \& Narus, J. A. (1998). Business marketing: understand what customers value. Harvard business review, 76, 53-67.

[22] Pappu, R., Quester, P.G. and Cooksey, R.W. (2005), "Consumer-based brand equity: improving the measurement - empirical evidence", Journal of Product \&Brand Management, Vol. 14, Nos 2/3, pp. 143-55.

[23] Aydin, S., \& Özer, G. (2005). National customer satisfaction indices: an implementation in the Turkish mobile telephone market. Marketing Intelligence \& Planning.

[24] Shocker, A. D., Srivastava, R. K., \& Ruekert, R. W. (1994). Challenges and opportunities facing brand management: An introduction to the special issue. Journal of marketing research, 31(2), 149-158.
[25] Farrington, T., Curran, R., Gori, K., O’Gorman, K. D., \& Queenan, C. J. (2017). Corporate social responsibility: reviewed, rated, revised. International Journal of Contemporary Hospitality Management.

[26] Torresa, Anna. A. Tribo, Josep. " Customer satisfaction and brand equity". Journal of Business Research Volume 64, Issue 10, October 2011, pp. 1089-1096.

[27] Mittal, V., \& Kamakura, W. A. (2001). Satisfaction, repurchase intent, and repurchase behavior: Investigating the moderating effect of customer characteristics. Journal of marketing research, 38(1), 131142 .

[28] Kim, W. C., \& Mauborgne, R. A. (2017). The W. Chan Kim and Renée Mauborgne Blue Ocean Strategy Reader: The Iconic Articles by Bestselling Authors W. Chan Kim and Renée Mauborgne. Harvard Business Review Press.

[29] Siu, N. Y. M., Zhang, T. J. F., \& Kwan, H. Y. (2014). Effect of corporate social responsibility, customer attribution and prior expectation on post-recovery satisfaction. International journal of hospitality management, 43, 87-97.

[30] Yoo, B., \& Donthu, N. (2001). Developing and validating a multidimensional consumer-based brand equity scale. Journal of business research, 52(1), 1-14.

[31] Miremadi, A., \& Khoei, R. (2013). The art of visual merchandising on consumer buying behavior. International Journal Contemporary Business Studies, 4(6), 34-50. 